\begin{tabular}{|l|l|}
\hline Jarnal Bimbingan dan Konseling Ar-Rahman \\
Volume 5, Nomor 2, Tahun 2019 \\
Tersedia Online: http://ojs.uniska.ac.id/index.php/BKA \\
e-ISSN 2477-6300
\end{tabular}

\title{
LAYANAN BIMBINGAN KELOMPOK DENGAN TEKNIK SOSIODRAMA UNTUK MENINGKATKAN KEJUJURAN SISWA KELAS VII A SMP NEGERI 17 BANJARMASIN
}

\author{
Mahfuzhatun Nisa, Kasypul Anwar, Nurul Auliah \\ ${ }^{1}$ Program Studi Bimbingan dan Konseling, Fakultas Keguruan dan Ilmu Pendidikan, Universitas Islam \\ Kalimantan Muhammad Arsyad Al Banjari Banjarmasin \\ mahfuzhatunn@gmail.com
}

\begin{abstract}
ABSTRAK
Penelitian ini dilatarbelakangi adanya siswa kelas VII A yang berperilaku tidak jujur, baik kepada guru maupun terhadap sesama siswa, seperti berbohong, mencontek, dan tidak membaca saat literasi. Tujuan dari penelitian ini untuk mengetahui tingkat kejujuran siswa sebelum dan sesudah diberikan layanan bimbingan kelompok dengan teknik sosiodrama dan untuk mengetahui keefektifan layanan bimbingan kelompok dengan teknik sosiodrama dalam meningkatkan kejujuran siswa. Metode penelitian kuantitatif dengan desain experiment one group pretest and posttest. Populasi sebanyak 29 orang dan sampel sebanyak 8 orang. Hasil penelitian skor siswa sebelum diberikan layanan berada dalam kategori rendah dan setelah diberikan layanan berada dalam kategori sedang. Hasil uji hipotesis sig 0,05 > 0.012, jadi Ha diterima dan Ho ditolak maka layanan bimbingan kelompok efektif dalam meningkatkan kejujuran siswa kelas VII A SMP Negeri 17 Banjarmasin. Saran bagi guru BK untuk menerapkan layanan bimbingan kelompok dengan teknik sosiodrama dalam sesi pembelajaran. Bagi siswa dapat membudayakan kejujuran dalam kehidupan. Bagi peneliti selanjutnya untuk dapat menggunakan waktu dengan baik.
\end{abstract}

Kata Kunci: Kejujuran; Bimbingan Kelompok; Sosiodrama

\begin{abstract}
This research is motivated by the existence of class VII A students who behave dishonestly, both to the teacher and to fellow students, such as lying, cheating, and not reading during literacy. to find out the effectiveness of group guidance services with sociodrama techniques in improving student honesty. Quantitative research methods with one group pretest and posttest experimental design. The population is 29 people and the sample is 8 people. The results of the study scores of students before being given services are in the low category and after being given services are in the medium category. Hypothesis test results sig 0.05>0.012, so Ha is accepted and Ho is rejected, the group guidance service is effective in improving the fairness of Grade VII A students of SMP Negeri 17 Banjarmasin. Suggestions for BK teachers to implement group guidance services with sociodrama techniques in learning sessions. For students to be able to cultivate honesty in life. For future researchers to be able to use time well.
\end{abstract}

Keywords: Honesty, Group Guidance; Sociodrama

Dipublikasikan Oleh :

UPT Publikasi dan Pengelolaan Jurnal

Universitas Islam Kalimantan Muhammad Arsyad Al-Banjari Banjarmasin 
Mahfuzhatun Nisa, Kasypul Anwar, Nurul Auliah

Jurnal Bimbingan dan Konseling Ar-Rahman

Volume 5, Nomor 2, Tahun 2019

e-ISSN 2477-6300

\section{PENDAHULUAN}

Perkembangan zaman yang semakin pesat saat ini banyak mengalami perubahan serta kemajuan, baik dalam aspek sosial, aspek budaya, maupun aspek yang lainnya. Perubahan itu tentu ada menimbulkan dampak, baik itu dampak positif maupun dampak negatif.Jika dampak positif maka akan menguntungkan dan jika dampak negatif maka akan merugikan dan menimbulkan permasalahan.

Salah satu tanda yang bisa menimbulkan permasalahan dan bisa menghancurkan suatu bangsa menurut Thomas Lickona (Kurnia, 2014) adalah perilaku membudayanya ketidakjujuran. Hal ini tentu sangat memprihatinkan karena jika perilaku jujur hilang dalam diri individu maka akan menimbulkan krisis kepercayaan dalam kehidupan, bahkan bisa sampai menimbulkan dampak dalam kehidupan berbangsa dan bernegara.

Wakil Ketua DPR, Pramono Agung menyatakan bahwa kejujuran di negeri ini semakin langka. Sering kali jika kita berkata jujur malah dituding bohong. Beberapa pemberitaan di media massa, praktik korupsi telah merajaleladilakukan oleh oknum pejabat pemerintah, bahkan oleh oknum guru. Menjamunya budaya nyontek, plagiarisme, pengkatrolan nilai oleh guru, dan korupsi mengajar merupakan bukti nyata bahwa bangsa ini sedang mengalami krisis kejujuran dalam dunia pendidikan (Kurnia, 2014, hal. 8).

Humaidi (Malik, 2015, hal. 3) menyebutkan bahwa kebenaran (kejujuran) adalah sendi yang terpenting bagi tegaknya masyarakat, sebab dengan adanya kebenaran maka akan tercipta pengertian satu sama lain dalam masyarakat, dan tanpa adanya saling pengertian tidak akan terjadi saling tolong menolong, sedang bahasa diciptakan juga untuk saling pengertian ini, yang tanpa itu tidak mungkin terjadi kehidupan masyarakat.

Kejujuran dalam konteks pembangunan karakter di sekolah menjadi sangat penting untuk menjadikan karakter peserta didik saat ini sebagai bekal mengarungi kehidupan di masa yang akan datang. Karakter seperti itu dapat dilihat secara langsung di dalam kelas, semisal ketika peserta didik melaksanakan proses pembelajaran maupun melaksanakan ujian. Perbuatan mencontek merupakan perbuatan yang mencerminkan peserta didik berbuat jujur kepada diri, teman, orang tua, dan pendidiknya (Malik, 2015, hal. 4).

Dalam dunia pendidikan, nilai kejujuran perlu dikembangkan untuk menghasilkan sumber daya yang dapat menjunjung tinggi nilai-nilai kejujuran.Pendidik atau dosen memiliki peranan penting dalam membangun karakter, kepribadian, dan intelektual peserta didik (Ungusari, 2015, hal. 2)

Berdasarkan kasus tersebut kejujuran dalam konteks pembangunan karakter di sekolah menjadi begitu penting untuk menjadikan karakter siswa saat ini sebagai bekal dalam kehidupan di masa yang akan datang. Maka dari itu pendidikan memiliki peran yang penting dalam kehidupan dengan tujuan membentuk watak dan kepribadian manusia.

Berdasarkan hasil observasi di kelas VII A SMP Negeri 17 Banjarmasin terlihat bahwa siswasiswi sering berperilaku tidak jujur, baik terhadap guru maupun terhadap sesama siswa. Ketidakjujuran tersebut misalnya siswa sering keluar kelas dengan alasan tertentu padahal mereka keluyuran di luar kelas atau pergi ke kantin, banyak siswa yang tidak mengerjakan PR dengan beralasan ketinggalan, mencontek, dan tidak membaca buku saat jam literasi sudah dimulai. Selain itu berdasarkan hasil wawancara dengan guru bimbingan dan konseling ternyata ketidakjujuran siswa kelas VII juga dirasakan saat diberikan tugas oleh guru BK mereka banyak yang mencontek dan saat literasi banyak siswa yang tidak membaca buku. Hal itu berdampak buruk bagi diri siswa itu sendiri.

Bimbingan dan konseling memiliki peran penting dalam membentuk watak dan kepribadian manusia. Salah satunya layanan yang bisa dilakukan seperti penelitian yang dilakukan oleh Yusuf Hasan Baharuddin mengenai "Konseling Kelompok Berbasis Nilai-Nilai Islam Untuk Meningkatkan Kejujuran Siswa (Studi Eksperimen di SMP-IT Masjid Syuhada Yogyakarta terlihat bahwa layanan konseling kelompok efektif dalam meningkatkan kejujuran siswa.

Cara lain yang bisa dilakukan oleh guru BK yaitu dengan memberikan layanan bimbingan kelompok. Menurut Tohirin (Herwanto, 2018) layanan bimbingan kelompok merupakan suatu cara memberikan bantuan (bimbingan) kepada individu melalui kegiatan kelompok dan membahas topik yang berguna bagi pengembangan dan pemecahan masalah anggota kelompok. Pelayanan bimbingan kelompok dimaksudkan untuk memungkinkan siswa secara bersama-sama memperoleh fungsi utama bimbingan yang didukung oleh layanan konseling kelompok ialah fungsi pengentasan (Jannah, 2015).

Bimbingan kelompok juga dapat dimaksudkan untuk meningkatkan pemahaman tentang kenyataan, aturan-aturan dalam kehidupan, dan cara-cara yang dapat dilakukan untuk menyelesaikan tugas, serta meraih masa depan dalam studi, karir, ataupun kehidupan. Aktivitas kelompok itu sendiri dapat diarahkan untuk memperbaiki dan mengembangkan pemahaman diri dan pemahaman lingkungan, penyesuaian diri, serta pengembangan diri (Eriana, 2018, hal. 15).

Selain itu dalam melaksanakan layanan bimbingan kelompok perlu teknik yang gunakan. Salah satu teknik yang bisa digunakan yaitu teknik sosiodrama. Sosiodrama menurut Roestiyah (Bingah, 
2015) adalah dramatisasi perilaku atau ungkapan gerak-gerik wajah seseorang dalam hubungan sosial antara manusia.

Sosiodrama berupa sandiwara, tetapi isinya berupa persoalan-persoalan yang berkaitan dengan gangguan serius dalam kesehatan mental para partisipan, sehingga tujuannya ialah perombakan dalam struktur kepribadian seseorang. Sosiodrama menekankan aspek perkembangan sosial seseorang, bukan inti paling dasar dalam kepribadiannya. Oleh karena itu sosiodrama merupakan kegiatan yang dapat sangat cocok untuk membantu banyak orang muda dalam meningkatkan perkembangan sosialnya. Sosiodrama sangat sesuai sebagai dalam kegiatan dalam rangka program bimbingan kelompok.(Dinata, 2016, hal. 29).

Berdasarkan kasus ketidakjujuran kelas VII A yang ada di SMP Negeri 17 Banjarmasin, maka peneliti tertarik untuk melakukan layanan bimbingan kelompok dengan teknik sosiodrama. Tujuan dari adanya penelitian ini untuk mengtahui tingkat kejujuran siswa kelas VII A sebelum diberikan layanan bimbingan kelompok dengan teknik sosiodrama, untuk megetahui tingkat kejujuran siswa kelas VII A sesudah diberikan layanan bimbingan kelompok dengan teknik sosiodrama, dan untuk mengetahui keefektifan layanan bimbingan kelompok dengan teknik sosiodrama dalam meningkatkan kejujuran siswa kelas VII A SMP Negeri 17 Banjarmasin.

\section{METODE}

Metode penelitian yang digunakan dalam penelitian ini ada metode kuantitatif dengan desain penelitian pre experimental design pretest posttest (Sugiyono, 2015). Prosedur yang dilakukan dalam penelitian ini yaitu responden diberikan pretest untuk menentukan sampel, kemudian sampel yang telah didapat diberikan layanan bimbingan kelompok dengan teknik sosiodrama sebanyak tiga kali, dan terakhir diberikan posttest untuk mengukur peningkatan kejujuran siswa.

Jumlah populasi yang diambil kelas VII A sebanyak 29 orang dan diambil sampel dengan teknik purposive sampling sebanyak 8 orang. Kriteria inklusi dan eksklusi dalam teknik purposive sampling ini sebagai berikut:

Tabel 1. Kriteria Inklusi dan Eksklusi

\begin{tabular}{ll}
\hline \multicolumn{1}{c}{ Inklusi } & \multicolumn{1}{c}{ Eksklusi } \\
\hline Siswa SMPN 17 Banjarmasin & Tidak siswa SMPN 17 Banjarmasin \\
Siswa kelas VII A & Tidak siswa kelas VII A \\
Umur 13-14 tahun & Tidak berumur 13-14 tahun \\
Memiliki kejujuran yang rendah & Memiliki kejujuran yang tinggi \\
\hline
\end{tabular}

Alat ukur yang digunakan dalam menentukan kejujuran siswa berupa angket kejujuran dengan skala Likert dengan jumlah pertanyaan sebanyak 100 item. Uji validitas menggunakan Pearson Correlation dan dilakukan dengan SPSS 25 ditentukan $r$ tabel sebesar 0.176 dari 100 item terdapat 22 item yang gugur dan 78 item yang dipakai sebagai instrumen penelitian. Selain itu uji reliabilitas menggunakan Alpha Cronbach dengan hasil 0,740 yang mana hasil tersebu lebih besar dari minimal Cronbach's Alpha 0,6. Oleh karena itu dapat disimpulkan instrumen penelitian yang digunakan untuk mengukur skala kejujuran siswa dikatakan Riabel atau Heandel.

Hipotesis yang digunakan dalam penelitian ini yaitu ada atau tidaknya pengaruh layanan bimbingan kelompok dalam meningkatkan kejujuran siswa kelas VII A SMP Negeri 17 Banjarmasin. Teknik analisis data yang digunakan dalam penelitian ini adalah menggunakan statistik deskriptif dan uji Wilcoxon. Statistik deskriptif adalah statistik yang digunakan untuk menganalisis data dengan cara mendeskripsikan atau menggambarkan data yang telah terkumpul sebagaimana tanpa adanya bermaksud membuat kesimpulan yang berlaku umum atau generalisasi. Selain itu penggunaan Uji Wilcoxon untuk menganalisis hasil-hasil pengamatan yang berpasangan dari dua data apakah berbeda atau tidak (Sugiyono, 2015, hal. 208-209).

\section{HASIL DAN PEMBAHASAN}

Gambaran hasil penelitian kejujuran siswa kelas VII A selum dan sesudah diberikan layanan bimbingan kelompok dengan teknik sosiodrama dapat dilihat pada tabel 2 .

Tabel 2. Perbedaan Hasil Skor Kejujuran Siswa Sebelum dan Sesudah Diberikan Treatment

\begin{tabular}{|c|c|c|c|c|}
\hline \multirow{2}{*}{ Nama } & \multirow[b]{2}{*}{$\begin{array}{c}\text { Skor } \\
\text { Pre-test }\end{array}$} & \multicolumn{3}{|c|}{ Skor } \\
\hline & & Kategori & $\begin{array}{c}\text { Post- } \\
\text { test }\end{array}$ & Kategori \\
\hline $\mathrm{AH}$ & 127 & Rendah & 153 & Sedang \\
\hline $\mathrm{AW}$ & 124 & Rendah & 160 & Sedang \\
\hline BMB & 129 & Rendah & 155 & Sedang \\
\hline LD & 132 & Rendah & 152 & Sedang \\
\hline MAR & 135 & Rendah & 158 & Sedang \\
\hline MF & 134 & Rendah & 179 & Sedang \\
\hline NSAG & 132 & Rendah & 148 & Sedang \\
\hline RAM & 131 & Rendah & 158 & Sedang \\
\hline Total & & & & 263 \\
\hline
\end{tabular}


Mahfuzhatun Nisa, Kasypul Anwar, Nurul Auliah

Jurnal Bimbingan dan Konseling Ar-Rahman

Volume 5, Nomor 2, Tahun 2019

e-ISSN 2477-6300

Berdasarkan tabel 1 dapat dilihat bahwa terlihat perbedaan skor kejujuran siswa antara sebelum dan sesudah dilakukan layanan bimbingan kelompok dengan teknik sosiodrama. Hal itu terlihat juga dari kategori yang pada awalnya kejujuran siswa berada pada ketegori rendah, namun setelah dilakukan layanan bimbingan kelompok dengan teknik sosiodrama kejujuran siswa meningkat menjadi kategori sedang. Perbedaan hasil skor juga dapat dilihat pada gambar 2 .

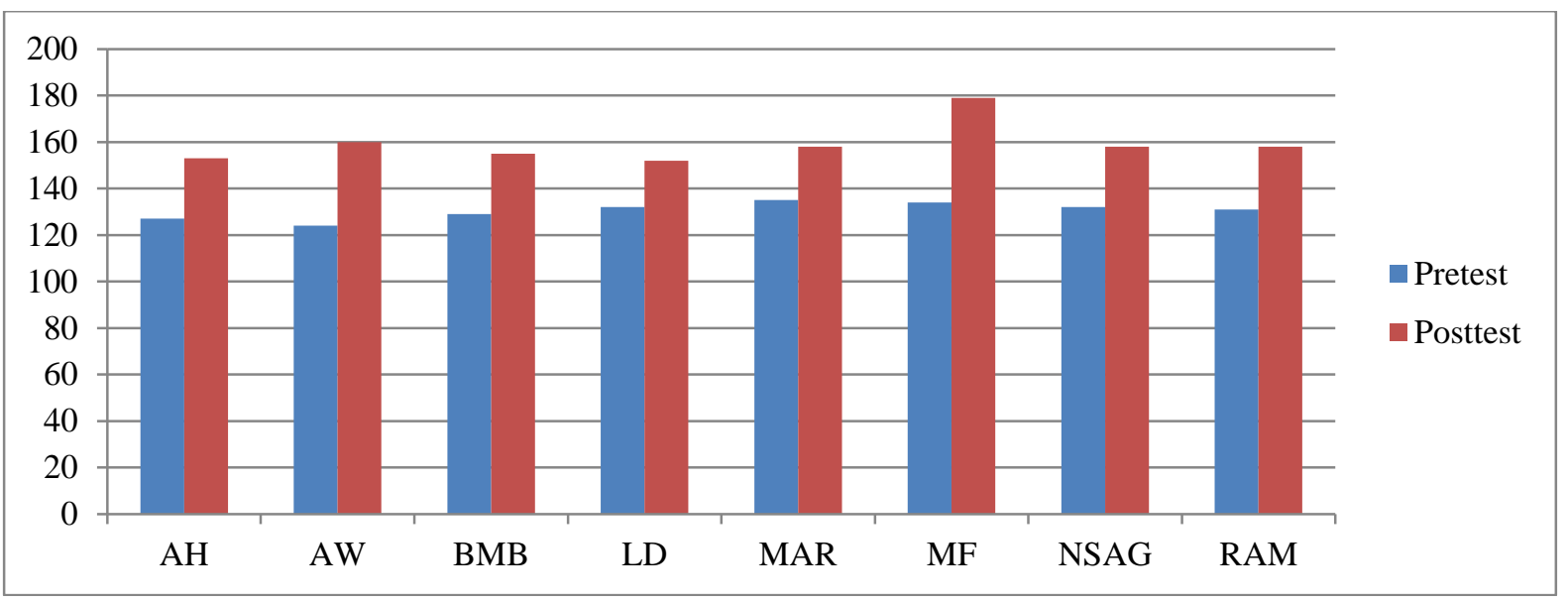

Gambar 1. Grafik Hasil Pretest dan Posttest

Dari grafik diatas terlihat adanya peningkatan skor pretest (sebelum) dan posttest (sesudah) diberikan layanan bimbingan kelompok teknik sosiodrama. Selanjutnya pengujian hipotesis menggunakan uji wilcoxon. Hasil dari uji wilcoxon dapat dilihat pada tabel berikut.

Tabel 3. Hasil Uji Wilcoxon

\begin{tabular}{lc}
\hline & sesudah - sebelum \\
\hline $\mathrm{Z}$ & $-2.524^{\mathrm{b}}$ \\
Asymp. Sig. (2-tailed) & 0,012 \\
\hline
\end{tabular}

Untuk melihat hasil statistik jika nilai sig < 0,05 maka berhubungan nilai $Z_{\text {tabel }}$ untuk nilai sig 0,05 $=-2.524$. berdasarkan hasil perhitungan uji wilcoxon menggunakan SPSS maka diperoleh $\mathrm{Z}_{\text {tabel }}$ untuk nilai sig 0,012 jadi $Z_{\text {hitung }}$ sebesar -2.524 , karena nilai ini adalah mutlak sehingga tanda negatif tidak diperhitungkan. Maka dari itu nilai $Z_{\text {hitung }}$ menjadi 2.524. selanjutnya nilai $Z_{\text {hitung }}$ ini dibandingkan dengan nilai $Z_{\text {tabel }}$ dengan taraf signifikasi $8 \%$, harga $\mathrm{Z}_{\text {tabel }}=0$. Maka $\mathrm{Z}_{\text {hitung }}=2.524>\mathrm{Z}_{\text {tabel }}=0,012$ maka Ha dterima dengan demikian perilaku kejujuran terdapat perubahan setelah diberikan layanan bimbingan kelompok dengan teknik sosiodrama dilihat dari ketentuan $Z_{\text {hitung }}>Z_{\text {tabel }}$ dan Ho ditolak. Jadi dapat disimpulkan bahwa layanan bimbingan kelompok dengan teknik sosiodrama dapat meningkatkan kejujuran dari yang rendah menjadi sedang pada siswa kelas VII A SMP Negeri 17 Banjarmasin.

Dari adanya hasil uji wilcoxon di atas maka kejujuran siswa kelas VII A SMP Negeri 17
Banjarmasin dapat ditingkatkan melalui layanan bimbingan kelompok. Berdasarkan penelitian yang dilakukan oleh Yusuf Hasan Baharuddin bahwa kejujuran dapat ditingkatkan melalui Konseling Kelompok Berbasis Nilai-Nilai Islam. Selain itu penelitian yang dilakukan oleh Miftakhul Bingah bahwa layanan bimbingan kelompok dengan teknik sosiodrama dapat meningkatkan perilaku prososial siswa Kelas VII C SMPN 3 Ngadirojo. Maka dalam hal ini dapat diartikan bahwa layanan bimbingan kelompok dengan teknik sosiodrama efektif dalam meningkatkan kejujuran siswa kelas VII A SMP Negeri 17 Banjarmasin.

\section{PENUTUP}

Berdasarkan hasil penelitian dapat disimpulkan bahwa layanan bimbingan kelompok dengan teknik sosiodrama efektif dalam meningkatkan kejujuran siswa kelas VII A SMP Negeri 17 Banjarmasin yang dibuktikan adanya peningkatan skor hasil sebelum dan sesudah diberikan layanan bimbingan kelompok dengan teknik sosiodrama.

Dengan meningkatnya kejujuran siswa kelas VII A SMP Negeri 17 Banjarmasin maka bagi subjek penelitian dan siswa diharapkan dapat menerapkan dan membudayakan kejujuran yang telah ditingkatkan dalam kehidupan sehari-hari. Bagi pihak sekolah dan guru serta guru BK untuk dapat meninjau kejujuran siswa dan memberikan layanan bimbingan kelompok dengan teknik sosiodrama dan bagi peneliti selanjunya dapat memanfaatkan waktu dengan baik dalam melaksanakan penelitian. 


\section{REFERENSI}

Baharudin, Y. H. (2016). Konseling Kelompok Berbasis Nilai-Nilai Islam untuk Meningkatkan Kejujuran Siswa (Studi Eksperimen di SMP-IT Masjid SyuhadaYogyakarta),Skripsi.

Bingah, M. (2015). Upaya Meningkatkan Perilaku Prososial melalui Teknik Sosiodrama pada Siswa Kelas VII C SMPN 3 Ngadirojo Kab.Pacitan,Skripsi.

Dinata, M. H. (2016). Efektifitas Sosiodrama dalam Meningkatkan Perilaku Prososial Peserta Didik Kelas X Semsester Genap SMA Negeri 10 Bandar Lampung Tahun Ajaran 2015/2016, Skripsi. 29.

Eriana. (2018). Upaya Mengeksplorasi Karir Melalui Bimbingan Kelompok dengan Teknik Diskusi Kelompok di MAN 2 Barito Kuala, Skripsi.14-18.

Herwanto, R. (2018). Pengaruh Layanan Bimbingan Kelompok dengan Teknik Psikodrama untuk Meningkatkan Kepercayaan Diri pada Peserta Didik Kelas VIII di SMP Negeri 4 Bandar Lampung Tahun Pelajaran 2018/2019, Skripsi.

Jannah, N. (2015). Pelaksanaan Kegiatan Layanan Bimbingan Kelompok dalam Pemilihan Kegiatan Ekstrakurikuler di SMP Negeri 1 Rantau, Jurnal Mahasiswa BK An-Nur. 1.1. 43

Kurnia, A. D. (2014). Implementasi Nilai Kejujuran di Sekolah Dasar Negeri 5 Kotagede Yogyakarta, Skripsi.

Malik, A. (2015). Implementasi Pendidikan Karakter Kejujuran melalui Mata Pelajaran Sosiologi Kelas X di MAN Bangil Pasuruan, Skripsi.

Sugiyono. (2015). Metode Penelitian Pendidikan Pendekatan Kuantitatif, Kualitatif, dan R\&D. Bandung: Alfabeta.

Ungusari, E. (2015). Kejujuran dan Ketidakjujuran Akademik pada Siswa SMA yang Berbasis Agama, Skripsi. 3. 